\title{
Transnational Abductions and Transnational Responsibilities? The politics of 'protecting' female Muslim refugees abducted from Spain
}

\author{
Elena Fiddian-Qasmiyeh*
}

\section{Transnational Abductions and Transnational Responsibilities? The politics of 'protecting' female Muslim refugees abducted from Spain}

\begin{abstract}
This article examines evolving gendered protection narratives surrounding four 'abduction' cases in which Sahrawi refugee girls and young women living in Spain were 'abducted' by their birth families and forcibly returned to the Algerian-based Sahrawi refugee camps between 2002 and 2009. By exploring Spanish state and civil society responses to these girls' 'abductions', I argue that there has been a major shift in the ways in which legitimate responsibility and authority over Sahrawi refugee women as Muslim female forced migrants have been conceptualised and invoked by Spanish actors. I therefore assess the gendered nature of competing claims of responsibility to 'protect' Sahrawi refugee women both within and outside of the Algerian-based Sahrawi refugee camps, exploring the motivations and implications of different actors' in/actions towards these girls and women. With Polisario claiming to represent and act as a liberal 'state' committed to protecting the rights of its 'refugee-citizens' in some instances, whilst denying politico-legal responsibility in others, the question of 'who' or 'what' claims the legitimate authority to 'protect' Sahrawi refugee women and girls is thus accentuated by such cases. By exploring shifts in Spanish
\end{abstract}


public and political discourses of responsibility over the past decade on the one hand, and the accentuation of competing discourses as presented by Spanish, Polisario and Algerian actors on the other, the article highlights the complex nature and implications of the 'intimate' Spanish civil society networks which ensure the physical and political survival of the Sahrawi refugee camps.

Ultimately, I argue that Sahrawi girls and women have become hypervisible in Spain, being conceptualised as women who 'belong' to the Spanish nation which in turn has a responsibility to 'protect' 'our' Sahrawi women from 'their' culture.

Keywords: abduction; contested sovereignty; Orientalism; protection scenarios; refugee women; Sahrawi refugees

\section{Introduction}

Contrary to the earlier invisibility of women in migration studies, migrant and refugee women have become key protagonists in academic debates and policies surrounding the causes, nature and implications of different forms of migration (Indra 1989; Dustin and Phillips 2008). Multiple challenges posed by feminists to reportedly 'gender-neutral' understandings of 'voluntary' and 'forced' migration have led to the documentation of gendered causes and experiences of migration and displacement (Indra 1999; Mahler and Pessar 2006), recognising that gender relations and identities influence and are affected by living in refugee camps in the south (Fiddian-Qasmiyeh 2009), applying for asylum in the north (Bloch et al. 2000), or attempting to integrate into 'multicultural' host states and asylum states around the world (Matsuoka and Sorensen 1999). Debates prompted by feminists in the 1980s and 1990s motivated, amongst other things, an exploration of 
states', international organisations', and civil society's responsibility to 'protect' migrant and minority women from practices defined by Western observers as 'abusive,' 'illiberal' and 'violent,' focusing on practices including 'forced marriage', 'child marriage' or 'female genital surgeries' (Okin 1998; Cohen et al. 1999; Phillips 2003, 2007).

While campaigns and legislation have been developed to protect minority citizen women and female migrants from such forms of violence in Western states (ibid), legal and policy frameworks have also been developed by states and bodies such as the United Nations High Commissioner for Refugees (UNHCR) to protect refugee women from violence in southern-based refugee camps (UNHCR 1995), and to recognise these practices and other forms of gender-based persecution as grounds for asylum in the north (i.e. Canadian IRB 1996; UNHCR 2002, 2009). Such guidelines and policies institutionalise the international community's responsibility to protect girls and women from what are perceived to be religiously, culturally and politically sanctioned forms of gender-based violence in their places of origin. Indeed, far from the earlier invisibility of migrant women and Western states" "laissez-faire tolerance or indifference" (Phillips and Dustin 2004, 419), shifts within academia and state policies have led to migrant and refugee women's rights coming to be "at the top of the political agenda" (Roggeband and Verloo 2007, 271). The need to 'protect' migrant and minority women has thus emerged as "an 'emblematic' policy problem" (272) for Western states active not only within their own territory, but also across the south through development and humanitarian programmes and, in certain instances, even via military interventions. 
However, not all migrant or refugee women are perceived to be equally vulnerable or in need of protection; rather, "the category of migrant women is shrinking" in Europe, with concerns about "gender and migrants' rights" increasingly revolving around Muslim migrant women (Roggeband and Verloo 2007, 283). Indeed, regarding asylum-seeking and refugee women, Akram (2000) and others (incl. Fiddian-Qasmiyeh 2010) have critiqued the development and institutionalisation of neo-Orientalist protection narratives and politico-legal structures which construct Muslim refugee women as eternal victims of what is monolithically portrayed as an intrinsically violent and barbaric religion. Western state and non-state policies ostensibly designed to 'protect' migrant and refugee women in the public and private spheres are thus revealed to be based upon a "discursive strategy that constructs gender subordination as integral only to certain [non-Western] cultures" solidifying a separation and hierarchy between 'us' (liberal, equal) and 'them' (illiberal, barbaric and oppressive of women), for highly political purposes (Volpp 2001, 1181). By opposing race and religion with gender in such debates, the 'positional superiority' of Western culture is reinforced over Other cultures (Nader 1989) as a means of justifying Western intervention to "save brown women from brown men" (Spivak 1993, 93). Western actors have thus established violence against Muslim migrant women as a central concern, proposing the necessity of 'saving' these women from 'their' 'culture,' and perceiving the West as being responsible for solving this problem across a range of geographies.

With these debates and criticisms in mind, this article examines Spanish civil society and institutional responses to the 'abductions' of four Sahrawi refugee girls and women for whom state responsibility is both unclear and highly politicised. After a brief 
overview of the Sahrawi refugee situation, the article examines two sets of case-studies involving Sahrawi girls and young women who left their Algerian-based refugee camps as young teenagers to live and study in Spain. By exploring Spanish state and civil society responses to these girls' 'abductions' by their birth-families and their forced return to the Sahrawi camps, I argue that there has been a major shift in the ways in which legitimate responsibility and authority over Sahrawi refugee women as Muslim female forced migrants have been conceptualised and invoked by Spanish actors. Hence, Spanish responses to the separate 'abductions' of Aicha, Huria and Fatimetu in the early2000s all revolved around the demand that Polisario Front, as the Sahrawi's 'legitimate' political representatives and effective leaders of the Sahrawi state-in-exile, should be held accountable for these young women's 'abductions' by their birth-families, meeting Spanish cultural, political and legal norms accordingly. Unlike these early cases, recent legal and political events in Spain surrounding the abduction of Mimouna in 2008-2009 reflect a move away from Spanish families and civil society summoning Polisario’s responsibility over Sahrawi women, towards invoking Algeria's responsibility as Sahrawi refugees' 'host state' and de-jure authority over the camps. Overall, this article therefore identifies and examines the competing nature of Spanish, Polisario and Algerian claims vis-à-vis jurisdictional responsibility over Sahrawi refugee women in Spain and in the Algerian-based refugee camps, exploring the motivations and implications of different actors' in/actions. By exploring shifts in Spanish public and political discourses of responsibility over the past decade on the one hand, and the accentuation of competing discourses presented by Spanish, Polisario and Algerian actors on the other, the article highlights the complex nature and implications of the 'intimate' Spanish civil society 
networks which ensure the physical and political survival of the Sahrawi camps. Ultimately, I argue that Sahrawi girls and women have become hypervisible in Spain, being conceptualised by Spanish observers as 'belonging' to Spanish families and the Spanish nation which are represented as holding legitimate responsibility to ensure the 'protection' of 'our' Sahrawi girls and women from 'their' oppressive familial and cultural practices and traditions.

This article analyses the content, discursive frames and aims of high-profile 'liberation' campaigns mobilised in Spain as a response to these four 'abductions'. These campaigns were selected due to their highly public and politicised nature, and the article therefore examines publically available sources produced and distributed in Spain over the course of over a decade. ${ }^{1}$ The analysis of these sources draws on insights derived from three fieldwork visits to the Saharawi refugee camps (2001-2007), and extensive research conducted with and about Sahrawi adults and children in Algeria, Cuba, Libya, South Africa, Spain and Syria (2001-present), including over 100 interviews with Sahrawi refugees, and more than 40 interviews with Spanish humanitarians (FiddianQasmiyeh 2009, 2010, 2011).

Importantly, given the nature of these campaigns, only certain voices and discourses have been publically projected, with the young women and their fosterfamilies, alongside Spanish lawyers, judges and journalists, and the official Polisario representatives having been hypervisible and hyperaudible in media and political accounts. In contrast, in the first set of cases, the perspectives of Aicha's, Huria's and Fatimetu's birth-families remained entirely absent from the Spanish public sphere, while 
in the more recent 'abduction' case, Mimouna's father and brother have occasionally been cited by the Spanish media.

Before turning to the 'abductions', a brief overview of the Western Saharan conflict and an introduction to the Sahrawi refugee camps and their support structures is necessary.

\section{Brief history}

A Spanish colony from 1884-1975/1976, the Western Sahara was placed on the UN Decolonisation Committee's agenda in 1964. Anti-colonial movements developed in the 1960s and 1970s, and in 1973, the Polisario Front was born, gaining popular support as it firstly resisted Spanish colonialism, and later Moroccan and Mauritanian claims over the territory. Although Spain conducted a census of the population in December 1974 to prepare for a referendum for self-determination, Spain withdrew from the territory in late-1975. Rather than leading to decolonisation, 350,000 Moroccan civilians entered the territory in November 1975, facing no resistance from Spanish or international forces, as part of the 'Green March' designed to recover the Moroccan state's 'Southern Provinces.' Approximately 20,000 Moroccan soldiers soon joined from the North (Chopra,1999), while Mauritanian forces entered from the South, ignoring UN Resolutions which deplored the march and called for its termination (i.e.Res.380, 6 November 1975).

Following Franco's death, the armed conflict between Morocco, Mauritania and Polisario intensified, with a mass Sahrawi exodus being displaced to other parts of the territory, and later, following the bombardment of these first encampments (Mercer 1979), to the 
nascent Algerian-based refugee camps near these countries' common border (for a detailed history, see Fiddian-Qasmiyeh 2009).

Since the mid-1970s, Polisario has governed and administered the Sahrawi refugee camps and its refugee population (approximately 155,000 people) via the Sahrawi Arab Democratic Republic (SADR), the 'state in exile' constituted by Polisario on 27 March 1976 (one day after Spain officially withdrew from its colony and unilaterally declared that it was no longer the administrating power). Polisario/SADR has its own constitution, camp-based police force, army and parallel state and religious legal systems. The constitution states that Polisario will remain the only authorised political group until an independent Western Sahara is established; opposition parties are not permitted, and internal challenges to Polisario's authority have been repressed since the camps’ establishment (Amnesty International 1996; HRW 2008, 116).

Unlike refugee camps which are controlled by international organisations such as the UNHCR, Polisario/SADR is "the only authority with which [Sahrawi] camp residents have regular contact" (HRW 2008, 9). Despite being on Algerian territory, the Algerian government has effectively "ceded de facto administration" to Polisario/SADR (ibid), enabling them to "manage their own civil society and social systems without interference” (WFP 2009-2010, 7; Fiddian-Qasmiyeh 2011). Such high levels of selfmanagement and Polisario's de facto control over the Algerian territory upon which the camps have been built, distinguish the Sahrawi camps from the majority of refugee camp contexts around the world.

Polisario/SADR's camp-based administrative and institutional capacities have been widely commended by international observers, with the camps denominated "the 
best run refugee camps in the world" and "models of efficient local government" (Brazier 1997, 14). Indeed, in her seminal work, Imposing Aid (1986), Harrell-Bond labelled the Sahrawi camps a 'success story' amidst a failing system which creates 'dependency syndrome' amongst refugees (also Voutira and Harrell-Bond 2000, 66). Importantly, a range of intersecting claims have been projected internationally to demonstrate the 'ideal' nature of Polisario/SADR and 'its' camps, including in a 1986 report written following an Oxfam desk-officer's visit to the camps:

Perhaps the most impressive thing about Sahrawi society is that it is the most fundamentally balanced society I have ever come across in terms of the relationships between men and women (Mowles 1986, 9).

As I have argued elsewhere, gender equality and women's 'empowerment' have become central and recurrent features in both Polisario/SADR and Western accounts of life in the Sahrawi camps (Fiddian-Qasmiyeh 2009, 2010, 2011). Mainstream academic and civil society claims regarding the 'ideal' nature of the camps demonstrate that while Polisario/SADR has constructed and developed the camps internally, this 'liberation movement' has concurrently obtained the approval of key actors in the international arena by adhering to "the trinity of democratisation, good governance and women's rights" (Kandiyoti 2004, 134).

Indeed, since its birth in 1973, Polisario/SADR has been recognised as the 'legitimate' representatives of the Saharawi people by over 70 non-Western states worldwide, and political conflicts have ensued between states and organisations (such as Algeria and the Organisation of African Union) which recognised and lobbied in favour 
of Polisario/SADR's struggle for independence, and those which did not. From 1976 to the present, the Western Saharan conflict has thus been dominated by Morocco and Polisario attempting to convince state and non-state actors to support their respective political standpoints, and recognise the legitimacy of their claims over the territory and its inhabitants.

Polisario/SADR has been widely successful in its 'international relations strategy' (Fiddian-Qasmiyeh 2009), with the camp-based SADR having full diplomatic relations with the abovementioned states and key regional bodies such as the African Union (AU). As a full member of the Organisation of African Unity (OAU) and later AU, SADR has signed and ratified numerous African Human Rights Charters (including those pertaining to the Rights and Welfare of the Child, and the Rights of Women in Africa), and its Constitution also refers to the Universal Declaration of Human Rights, thereby effectively rendering itself accountable to these international human rights frameworks.

However, although SADR is recognised as a state by over 70 states, and has acted "as a state” by ratifying OAU/AU regional human rights conventions, Polisario holds neither observer status at the UN (Wilson 1988, 141), nor any other form of official status or recognition before the UN (OHCHR 2006). Indeed, the Office of the United Nations High Commissioner for Human Rights (OHCHR) notes that Polisario/SADR "has no international obligations under international human rights treaties," arguing that it is Algeria, as the host state, which is legally responsible for all Sahrawi refugees residing in its territory (OHCHR 2006, 11). Specifically, OHCHR notes that although Algeria "holds that it bears no responsibility with regard to the human rights situation of the Sahrawi people" (since Algeria recognises SADR's jurisdiction and, in effect sovereignty, over 
the camps), "no international human rights treaty body has specifically validated this view with regard to the international human rights obligations accepted by Algeria" (13). In OHCHR's view, “Algeria should take all relevant measures to ensure that all individuals present on its territory benefit from the protection of the international human rights conventions to which it is a party" (13). Simultaneously, however, Human Rights Watch (HRW) argues that "although Algeria remains ultimately responsible ... Polisario needs to be accountable for how it treats the people under its administration" (HRW 2008, 9).

An anomalous situation thereby exists whereby Polisario/SADR is simultaneously recognised as a state by some members of the international community, presents itself as a state which is obliged to adhere to central tenets of international human rights law and specific obligations to protect women and children, and yet is also classified as a nonstate actor by the UN and other actors who argue that "it has no international obligations under international human rights treaties" (OHCHR 2006, 13) and therefore cannot formally be held accountable to the Charters which it has signed 'as a state'. This case is therefore not only relevant to on-going debates surrounding the responsibilities of nonstate actors in armed conflict around the world, but also raises specific questions surrounding the responsibilities of state, quasi-state, and non-state actors to 'protect' Sahrawi refugees living under the 'jurisdiction' of SADR. In the context of this article, precisely which actors consider themselves or are considered by others to be responsible to protect specific refugees - male or female, adult or child - becomes an even more pertinent issue. 


\section{Spain and Polisario}

In many countries which have not recognised SADR, Polisario has Representatives, rather than Ambassadors, who lobby national governments and civil society in favour of the Sahrawi 'cause' for independence. One such country is Spain, which has dozens of Representatives of the 'Sahrawi Government' (a term used widely in the Spanish media) across the country. Given this article's focus on Spanish actors' representation of gendered protection narratives pertaining to Sahrawi refugee women and girls since the early-2000s, a brief overview is necessary of the form and level of support offered by Spanish individuals and institutions, despite the Spanish government not having recognised SADR.

An extensive network of support for Polisario/SADR exists in Spain, including over 300 groups of 'Friends of the Sahrawi People' across the country (Crivello, Fiddian and Chatty 2005); more than 200 civil-society associations with over 14,700 active members coordinated by the Coordinadora Estatal de Asociaciones Solidarias con el Sahara (CEAS); and a federation of Spanish state institutions 'in solidarity' with the Sahrawi people. These and other groups lobby the Spanish government to resolve the Western Saharan conflict; regional and local organisations run significant development programmes in the camps and awareness-/fund-raising campaigns in Spain, and ensure that the refugee situation remains on national and international political radars. They also help to coordinate the 'Holidays in Peace' programme which allows 10,000 Sahrawi children aged 8-12 to spend the summer months in Spain, thereby allowing them to avoid the hottest periods in the camps (Crivello and Fiddian-Qasmiyeh 2010). 
Spanish host-families then travel to the camps en masse during the Easter and Christmas holidays, taking food, money, medicine, clothes and toys to 'their' Sahrawi family, thereby having the opportunity to see living conditions in situ. The connections built between Sahrawi and Spanish host-families during these visits are perceived by refugees as being essential for both their short-term and longer-term prospects, allowing children to benefit directly during the summer itself and to return to the camps bearing gifts, money, medical supplies and food for their immediate and extended families.

Highlighting the significance of the connections built between Sahrawi and Spanish families, the World Food Programme (WFP) identifies "the very vulnerable households" in the Sahrawi camps as those which "had not built any contacts with the civil societies of Spain and of other countries that provide support to refugee families" (WFP 2008, 3, emphasis added). In effect, it is this palpable connection and physical proximity to the people who provide such essential material and financial assistance, alongside social capital, which leads many Sahrawi families to recognise the significance of the support offered by Spanish civil society, in contrast with the less visible, and more taken-for-granted humanitarian projects which are marginalised in both the popular and the 'national' (Polisario/SADR) imagination (Fiddian-Qasmiyeh 2009). Following Betteridge's work on formal and personal gift exchange in Iran (1985), elsewhere I have argued that we could conceptualise this as a perceived distinction between invisible and anonymous 'official aid' and hyper-visible and personally granted 'intimate aid' (Fiddian-Qasmiyeh 2009).

This system of 'intimate aid' offers Sahrawi families and Polisario alike numerous possibilities: they increase families' social and financial capital, while bilateral 
agreements made with SADR Ministries and Polisario organs, including Polisario's Youth and Women's Unions, legitimate the Polisario/SADR's authority and capacity as a bona fide 'governmental' (or at least quasi-governmental) partner (Fiddian-Qasmiyeh 2009, 2010). Simultaneously, such connections have also led to conflicts and crises both between individual Spanish and Sahrawi families, and between Spanish actors and Polisario/SADR more broadly.

I will now examine a selection of cases characterised by Spanish actors overtly challenging Polisario/SADR to 'protect' Sahrawi girls and women in line with Spanish priorities. In the first set of cases, Polisario/SADR has been challenged by Spanish state and non-state actors to fulfil its politico-legal responsibilities towards 'its' female refugee-citizens as 'the Sahrawi Government,' thereby reinscribing Polisario/SADR as the de facto and legitimate authority over the camps and refugee inhabitants, and solidifying the representation of the Polisario/SADR as an entity which is deeply committed to upholding women's rights. In the second case-study, however, Polisario/SADR's claims to institutional 'state' power and mandate are explicitly contested through Spanish invocations of Algerian accountability as the, until now, largely 'invisible' host-state. In both instances, I argue that Spanish families and civil society on the one hand, and the Spanish state on the other are represented as holding legitimate responsibility to ensure the protection of 'our' Sahrawi girls and women from 'their' oppressive Sahrawi practices, thereby justifying the extension of Spanish 'tentacles' to 'rescue' them within and outside of Spain's national territory. ${ }^{2}$

\section{The early challenge: 'Abductions' and Polisario's 'responsibility' to protect}


As an extension of the summer hosting programme, large numbers of Sahrawi boys and girls have been fostered by Spanish families to facilitate access to secondary and tertiary educations and/or medical treatment in Spain (Crivello and Fiddian-Qasmiyeh 2010). Although Polisario/SADR does not officially approve of medium- to long-term fostering, whenever a Sahrawi child is fostered in Spain, the Sahrawi birth- and Spanish fosterfamilies sign a legal agreement before a Sahrawi state judge from the SADR Ministry of Justice and Religious Affairs. These documents specifies that: the host-family is granted temporary custody and guardianship of the child; the child is to be returned to his/her birth-family at the Sahrawi family's request; and the host-family is responsible for maintaining the child's family and cultural ties and facilitating regular communication with the child's parents and family (RASD 2000). ${ }^{3}$ The existence and terms of these contracts reflect Sahrawi families' concerns that their children might lose their cultural identity and linguistic abilities whilst living abroad (Chatty, Fiddian-Qasmiyeh and Crivello 2010; Crivello and Fiddian-Qasmiyeh 2010), whilst simultaneously echoing an Islamically-based understanding that adoption (and much less so fostering) creates neither legal nor relational ties between individuals (The Qur'an, sura 33, 4; Mernissi 2003, 57).

These agreements therefore highlight the temporary nature of fostering relationships, centralising the Sahrawi families' rights to maintain familial, cultural, legal and relational ties with their children despite the physical distance arising while their sons and daughters are hosted by Spanish families; equally importantly, the SADR Constitution defines the family as the fundamental unit of Sahrawi society, and notes the inviolability of the Sahrawi household. 
Ultimately, however, as the cases of Aicha, Huria and Fatimetu demonstrate, the enforcement of these informal agreements is highly problematic given the tentative status of Polisario/SADR as a quasi-state actor, fostered children's lack of citizenship, and the unequal political, legal, economic and social capital held by Sahrawi birth-families and Spanish foster parents. Indeed, despite Polisario/SADR officially distancing themselves from these fostering arrangements, Polisario/SADR has nonetheless been summoned by Spanish civil-society and political and legal institutions to intervene when conflicts have arisen between Spanish and Sahrawi families over Sahrawi girls and young women formerly been based in Spain. Importantly, rather than upholding the elements specified in the fostering agreements themselves, including Spanish foster-families' commitment to return Sahrawi children to their birth-family at the Sahrawi family's request, and to maintain the child's family and cultural ties, in the early-2000s Spanish families, civil society and politico-legal figures repeatedly demanded that Polisario/SADR intervene to uphold Spanish priorities vis-a-vis 'the best interests of the child,' or, more specifically, 'the best interests of the girl-child/young woman'.

Indeed, it is particularly noteworthy that no parallel high-profile cases involving boys or young men have emerged in the Spanish media, despite a number of Sahrawi boys/young men having been asked to return to the camps following short- and long-term fostering in Spain (interviews, 27 February Camp, April-May 2007). Given the lack of reliable information regarding the number or gender of Sahrawi children who are fostered in Spain, or the gender of those who are asked to return to the camps, it is difficult to identify precisely how fostering and 'returns' to the camps are gendered in nature. Nonetheless, it can be argued that the absence of Spanish media, legal and political 
campaigns relating to the return of boys and young men to the camps highlights the extent to which the 'abduction' of Sahrawi girls and young women has attracted the Spanish public's imagination and media coverage, in turn suggesting a particularly strong sense of responsibility towards the protection of Sahrawi girls and young women by virtue of their gender, age and nationality.

\section{Introducing the early cases}

Aicha, Huria and Fatimetu lived and studied in León, La Rioja and Asturias for seven, four and three years respectively before becoming the centre of a chain of Spanish media campaigns between 2001 and 2003 (also see Fiddian-Qasmiyeh 2006, 2010a). Aicha moved to Spain aged 12 to complete her secondary and tertiary education, while Huria and Fatimetu were fostered aged 11 and 12 respectively primarily for medical reasons: Huria due to serious dental complications, and Fatimetu because of her condition as a celiac (Fernández 2003). Despite the above-mentioned fostering contracts, Aicha returned only once in seven years to visit her family in the refugee camps, while Huria had not seen her biological parents for over 2 years (Díaz 2003). These experiences clearly reinforced their families' anxieties that they might eventually lose their daughters entirely. Shortly after the girls reached puberty, their parents separately asked them to return to the camps to help care for their mothers: Aicha's mother was enduring a highrisk pregnancy; another girl's mother had suffered a miscarriage, while the third had just recently given birth (Castaño-Boullón 2003; Guijarro 2003). All three women therefore reportedly required assistance and turned to their eldest daughters accordingly. In each case, the girls' Spanish host-families eventually allowed 'their' foster-daughter to visit 
the camps for a short period. However, when their birth-families told Aicha, Huria and Fatimetu, aged 19, 16 and 17 respectively, that they would have to stay in the camps with their families rather than return to Spain, the Spanish host-families asserted that the girls had been 'abducted,' and proceeded to vigorously lobby for their 'return home,' to Spain. The degree of Spanish public support mobilised by the Spanish foster-families to 'liberate' these young women from their birth-families cannot be overstated: in Aicha's case, 17,000 Spaniards in the city of León signed a petition for her immediate return (Cazón 2004; Peregil 2002), while 12,000 signatures were collected in Avilés supporting Huria’s 'liberation' (González 2003a); the relevant debates and legal arguments reached not only the Spanish public via the media, but also higher political institutions such as the Spanish Congress, Foreign Ministry, and Senate; many local-level and several highranking politicians offered Aicha and Huria their backing, and the Senate voted in June 2002 in support of Aicha's return to Spain (Cazón 2004, 187). Throughout these and other cases, Sahrawi refugees and events taking place in the Algerian-based Sahrawi refugee camps were categorised as 'domestic' and 'national' issues in the Spanish media, rather than an 'international one', indicating the extent to which the Sahrawi camps were perceived to be an extension of the Spanish national self.

Alongside general claims that Aicha, Huria and Fatimetu's rights to health and education were denied in the camps, the Spanish families and the girls themselves mobilised the Spanish press and political institutions through references to conditions in the camps, in particular claiming that Sahrawi family and cultural traditions violently oppress women's rights. Importantly, the extreme representation of the subjugation of Sahrawi refugee women which was repeatedly and purposefully projected by Aicha, 
Huria and Fatimetu, as well as by their Spanish host-families and much of the Spanish media was diametrically opposed to the Polisario/SADR and mainstream discourse vis-àvis 'ideal' Sahrawi gender relations referred to above.

For instance, in her letter to the Spanish Authorities, Aicha writes:

I feel I have been kidnapped, forced to adapt myself to so many traditions that I don't even know where to start ... If [X] doesn't manage to speak with [the smuggler] I will spend the rest of my life as my own family's prisoner, and I will be the crazy one who tried to escape because she didn't agree with her clan's rules ... (Embarek, N.D.).

Paralleling claims that Aicha's 'clan' had imprisoned her and forced her to adapt to alien 'traditions,' in a public letter addressed to the Queen of Spain, Huria denounces the Sahrawi way of life:

That is the reason why I ask for your help. Do you think this is just? Here the women wear the burqa. Their lives are like Afghan women's lives. So, please, help me to leave this place, I beg you. I don't want to live the life that they lead, I want them to see that it is possible to change all this and to have rights (Hamoudi 2003, emphasis added).

The terms and descriptions offered in these accounts, and especially the explicit references to Afghan women and the burqa, are clearly understood by these young women as epitomising the 'worst' possible conditions for Muslim women (also Stabile and Kumar 2005). Although Sahrawi women do not wear the burqa, the girls' invoked these terms to convince Spanish observers that their plight to flee the refugee camps and 
their birth-families to return to their Spanish families was simultaneously understandable, just and necessary. As such, they seem to have recognised that a key factor which may pressure Western individuals, families and institutions to intervene in a crisis, or may at least be provided as a justification for intervention, is a particular representation of a cultural and religious prison which unjustly oppresses and subjugates women. Indeed, as has now been extensively documented, summoning the image of forcibly veiled Afghan women is particularly pertinent given the extent to which "the plight of Afghan women was invoked as a humanitarian crisis justifying military intervention” (Kandiyoti, interviewed by Hammami 2005, 1352; Stabile and Kumar 2005).

Simultaneously, Huria's personal (and political) identification in the extract above demonstrates a rejection of the Sahrawi 'way of life,' speaking of, and thus Othering, her birth-parents and refugee community as 'them' and 'they', whilst aligning herself with her Spanish family's culture and civil norms (her imagined 'we' and 'us'). In this sense, Huria's physical separation from her birth parents while she was fostered in Spain can be perceived as resulting in a realignment of her sense of forming part of the Spanish Self to paraphrase de Beauvoir, although Huria may have been 'born' a Sahrawi girl, through the 'modernising' fostering experience she has 'become' a Spanish woman (also Nash 2005).

These images were paralleled and expanded upon by those members of the Spanish media who supported the teenaged refugees' 'release,' basing their reports on the specific details delineated in the young women's letters and the Spanish families' press releases, but concurrently drawing upon their own perceptions and beliefs surrounding 
Sahrawi gender relations. Hence, one internet journalist who has not visited the refugee camps describes Sahrawi society as:

a hell of ancestral customs which stamp on women's most elemental rights; ... where women never come of age to obtain these [rights] and choose their way of life, not even to choose a husband because their own father chooses one for them when they are still girls, or they sell them or trade them for two camels, two goats or two donkeys; where men make laws only for themselves, always leaving their women in the margins (Suarez 2003).

Upon Aicha's release, other journalists and commentators stated that Aicha had "won the battle against her parent's ignorance and egoism," parents who expected her to fulfil "the role that is reserved ... for all of her nation's first-born women: little more than slavery in the khayma [tent] in the refugee camps" (Alonso 2003, emphasis added); Alonso continues by stating that "Some religions and a certain Bedouin atavism keep women tied to the leg of the bed."

In all of these statements, Sahrawi society as a whole and Sahrawi parents more specifically are "constructed as timelessly misogynistic, barbaric and uncivilized," naturalising both a "rhetoric of the 'clash of civilizations' and Orientalist constructions of the East upon which such a clash is predicated" (Stabile and Kumar, on representations of Afghanistan 2005, 774). As such, these accounts directly paralleled the monolithic depictions of subjugated, isolated and violated 'third world women' which Mohanty (1988), Spivak (1993) and others vehemently reject. Support was thus explicitly obtained for Aicha, Huria and Fatimetu's 'liberation' from the camps via continuously negative 
references to the Muslim identity of the Sahrawi, pinpointing oppressive veiling and marriage practices, and identifying different forms of family-sponsored violence against women; in these instances, the depiction of the girls' biological families as illegitimate 'barbaric' oppressors is implicitly and at times explicitly contrasted with Spanish fosterfamilies' 'civilised' concern for 'their' (foster)daughters' well-being (also see Nash regarding representations of legitimate kinship amongst birth and adoptive parents, 2005). As I have suggested above and elsewhere (Fiddian-Qasmiyeh 2010a), the images mobilised in these public campaigns therefore parallel the Orientalist imagery which is habitually reproduced by the West apropos the Muslim Arab Other, representing the neocolonial foundations of the gendered protection narratives which justify Western interventions to 'protect' and 'liberate' Muslim women in the south and north alike.

The intersecting depictions arising in the case of Aicha, Huria and Fatimetu's abductions therefore led to many members of Spanish civil society advocating for the girls' 'liberation' from their oppressive birth parents and culture in the refugee camps, thereby directly engaging in "an Orientalist logic that paternalistically seeks to protect women" (Stabile and Kumar 2005, 775). Importantly, such gendered protection scenarios are dependent on both a 'polarization between 'us' and 'them,' but also [upon] caricatures and stereotypes which bear little resemblance to reality" (Stabile and Kumar 2005, 771; also Abu-Lughod 2002).

\section{Invoking Polisario's powers to protect}

In a selection of documents published at the time of Aicha's, Fatimetu's and Huria's 'abductions' by their parents, a range of actors highlighted their views regarding 
Polisario/SADR's responsibilities towards these girls. Aicha herself, aged 19, is quoted as stating that, "for what has happened to me, for what is happening now, and for what will happen in the future, I blame only the POLISARIO FRONT [sic] which is directing my life," with the same document indicating that Polisario had successfully traced her whereabouts and informed her, at the age of 21 , that they had negotiated her 'release' and her right to continue studying in Spain (Embarek, N.D.).

Aicha therefore suggests that Polisario was responsible for allowing her to be retained against her will throughout the almost two years she spent in the camps, and, eventually, for allowing her to return to Spain following the completion of an agreement between the Spanish and Sahrawi governments, and Aicha's family. This confidence in Polisario's power and capacity to convince the girls' parents to allow them to return to Spain in line with Polisario/SADR's stated commitment to women's rights is reflected in almost all of the other Spanish documents consulted. For instance, Huria's host-family states:

We ask that the Saharawi authorities intervene immediately so that the norms of the Saharawi Arab Democratic Republic can be fulfilled and Huria can return to Spain immediately to complete her medical treatment (N.A., N.D., emphasis added).

In relation to Fatimetu's retention in the camps despite her serious medical condition, the Riojan solidarity NGO indicates that:

Considering these events, and their seriousness, we find it incredible that the Polisario Front and the government of the SADR, which you direct, could allow this form of 
negligence towards the girls ... (Grupo de Amistad de la Comunidad de la Rioja 2001, emphasis added).

As these quotes indicate, whilst Polisario/SADR is a 'government-in-exile' and is wholly dependent on externally provided humanitarian aid, Aicha, the Spanish families and solidarity NGOs all asserted that Polisario was the organisation which should be approached to obtain the girls' release in line with international human rights standards. In this sense, Spanish families invoked their 'intimate' 'parental' concern over the girls' wellbeing to demand not only Spanish but also Sahrawi 'state' intervention in Sahrawi family life, summoning the state's 'legitimate' power over Sahrawi refugee girls and women based in private households in the Sahrawi refugee camps.

However, while Spanish families, civil society and politico-legal actors argued that Polisario/SADR should enact its state-like authority to protect these young women, the Polisario Delegation of Castilla y León issued a memorandum in relation to Aicha's case in which they outline what the Saharawi Authorities felt was Polisario's role vis-avis the crisis:

The Sahrawi authorities never become implicated between Sahrawi families and the hostfamilies given that they do not support temporary adoptions. In the case of Aicha...the Sahrawi authorities are making an effort to convince Aicha's parents, but, they do not guarantee anything given the sensitive nature of the case in Sahrawi society, and it is not possible to launch a crusade for the liberation of Sahrawi women, using Aicha's name as its motto, without knowing about the history and achievements in relation to Sahrawi women's position today (Delegación Saharaui Castilla y León 2002). 
Hence, whilst declaring that they are the sole and legitimate representatives of the Sahrawi people as a collectivity and as individual refugees, and claiming to be the government in charge of camps inhabited by powerful and active Sahrawi refugee women, in this and other declarations Polisario representatives in Spain highlighted that they could only attempt to convince Aicha's parents, but could not guarantee success. To an extent, this may allude to the delicate balance which grants Polisario/SADR authority within the camps, and the terms of the socio-political contract uniting Sahrawi refugees to 'their' representatives. In this sense, Polisario's role and power as the 'legitimate representatives' of the Saharawi people will only last as long as 'the Saharawi people' agree with its decisions and rulings, and such interventions are represented by Polisario/SADR as solely being acceptable in particular public spheres and over particular refugees. In contrast, attempts to influence family decisions over the treatment of particular (especially young and female) refugees within the household are portrayed as especially 'sensitive,' potentially interfering in intimate private spaces protected by the SADR Constitution and undermining the basic unit of Sahrawi society: the Sahrawi family.

Indeed, before the degree of Spanish public support for Aicha's 'liberation' had become clear, Polisario's representative in Spain at the time officially indicated that Polisario would not become involved in Aicha's case since it was "a very personal problem, between families" (quoted in Peregil 2002). Refusing to intrude in Sahrawi family life and parental decisions over their daughters, he argued that "if more silent methods had been used, this case could have been resolved" (ibid), reiterating claims that 
these girls' cases were 'private' rather than 'political' matters. However, having recognised that these Sahrawi families' decisions and acts had the potential to destabilise the public humanitarian/solidarity network which provides essential material and political support to the camps and the Sahrawi nationalist project, Polisario/SADR ultimately succumbed to the pressure applied by Spanish civil and political organisations and 'negotiated' the girls' 'release' from their biological parents, and their 'return' to Spain (Fiddian-Qasmiyeh 2006, 2010a).

A delicate balance is therefore constantly being negotiated between Sahrawis who recognise their dependence upon Spanish humanitarian aid and political support, and yet fear that the cohesion and continuity of their families and households, and broader camp society, may be at threat due to this dependence. Although SADR indicated in communications with HRW that "some Spanish families are profiteering from the tragic situations of Sahrawis to seize some children" (2008, 184, emphasis added), and a Sahrawi blogger adamantly concludes that "all of the solidarity offered by all of [the host-families in Spain] is not worth the risk of even one of our children being kidnapped [by delinquent solidarios]," Polisario’s decision to intervene in Sahrawi family life to 'protect' 'its' refugee women was ultimately directly influenced by Spanish pressure and at odds with local preferences (Wurud 2008).

While Spanish actors were therefore able to exert leverage over Polisario through threats to withdraw or withhold aid from the refugee camps, Polisario may simultaneously have recognised that a potential threat was emerging both to its internationally projected image of being the legitimate authorities of the camps, and, relatedly, of the camps as spaces of gender equality and freedom from violence against 
women (Fiddian-Qasmiyeh 2010). Indeed, by securing these girls' 'release', Polisario therefore demonstrated its capacity to exert its legitimate control over its refugee-citizens in the camps (male and female, adult and child), and simultaneously to uphold the key characteristics celebrated by Western audiences: democracy, good governance and women's rights. They were thus able to reinstate their position as the de facto authority over Sahrawi refugees as a whole, and, in line with their ratification of protocols relating to women's and children's rights, as the legitimate protectors of Sahrawi refugee girls and women more specifically.

While Spanish families, civil society and politico-legal actors challenged Polisario to uphold its status as a responsible, liberal 'government' and state by 'protecting' Aicha, Huria and Fatimetu in line with Spanish priorities, the experiences of Mimouna in 2008 and 2009 reveal a major shift in the ways in which the issue of responsibility and legitimate authority over Sahrawi young women has come to be conceptualised by Spanish state and non-state actors.

\section{Revisiting responsibility to protect: the 'later' challenge}

Unlike Aicha, Huria and Fatimetu, who had all been individually fostered by Spanish families in their early-teens, Mimouna left the Sahrawi refugee camps with her birthfamily to live in Spain in 1999. In August 2008, however, aged 19, Mimouna disappeared from Spain and was reportedly forcibly returned to the camps by her birth-family. While Aicha, Huria and Fatimetu were reclaimed by their Spanish foster-families, in Mimouna's case, it was her Spanish fiancé who reported her disappearance to the local court in Lucena, claiming that she had been kidnapped by her mother and siblings; had 
been forcibly taken from Spain to the Algerian port of Oran (reportedly at knife point); and was being retained against her will in the camps (Planelles 2009). For the first time, a reference to Mimouna's risk of being forced into marriage against her will in the camps was projected in the international arena (M.P. 2008a). No such assertions were ever made in the cases of Aicha, Fatimetu or Huria, whose 'Spanish families' did not justify their attempts to secure their return to Spain in this way.

Nonetheless, paralleling the cases of Aicha, Huria and Fatimetu, Mimouna's fiancé, friends and legal team called upon Polisario to secure her release. In their increasingly public statements, the fiancé and his lawyer called upon the 'Sahrawi government' in the camps, via its Polisario 'representatives' in Spain, to protect the human rights of 'its citizens' in general, specifically declaring that Polisario and the 'Sahrawi government' "have moral and legal obligations" to protect Sahrawi women (Radio Lucena 2009). Furthermore, as noted by the lawyer, a petition was launched with the specific objective to "make the Sahrawi authorities reflect, as they are the only ones who can get [Maimouna] out of the camps" (Caravaca 2009). In so doing, Mimouna's fiancé and his lawyer explicitly recognised Polisario's diplomatic presence in Spain and SADR's role in the camps, but stressed that their trust in SADR was conditional upon Polisario/SADR protecting Sahrawi women like Mimouna in the camps and beyond. Indeed, this case confirms the extent to which the broader Spanish-Sahrawi humanitarian and political support system is grounded upon gender-based conditionalities, demanding the intervention of state and non-state actors within and outside of Sahrawi households in the camps and in Spain alike (also Fiddian-Qasmiyeh 2009, 2010a). However, unlike the continued and continuous reference to Polisario as the main interlocutor and agent of 
'protection' in Aicha, Huria and Fatimetu's cases, Mimouna's fiancé and legal entourage eventually, on 8 January 2009, called upon the Sahrawis' Algerian host state to become involved to 'liberate' this Sahrawi woman.

\section{Sahrawi, Spanish or Algerian authority over Sahrawi female subjects?}

Spain's principal requests, as submitted by the Spanish judge to the Algerian authorities via a letter rogatory ${ }^{4}$ were twofold: that the Algerian authorities facilitate Mimouna's return to Spain on the grounds that she was a claimant and witness in a Spanish court case; that the Algerian court in the military town of Tindouf (the closest town to the refugee camps) should question Mimouna's mother and brothers apropos Mimouna's abduction, in addition to establishing the details of her treatment during the abduction and whilst held in the camps (Europa Press 2009a). In the meantime, the Spanish judge confiscated Mimouna's father's and brother's passports to prevent them from leaving the country, as they had remained in Spain while Mimouna was reportedly taken to the camps by her mother and other brothers (also M.P. 2008b). Limiting these two male relatives' mobility, and enforcing their presence within the Spanish national territory, was thus perceived as a key means to achieve Mimouna's freedom of movement in/from the camps and to secure her safe return to her legitimate home, Spain.

Spain's intervention is, legally speaking, understandable since the 'crimes' of 'abduction' took place on Spanish territory, and Spain therefore has clear jurisdiction over these cases. Furthermore, the abovementioned Spanish requests for Algeria's interventions are broadly in line with the arguments presented by HRW and OHCHR, as quoted above. HRW has also argued that: 
The government of the host country, Algeria-which is accountable under international law for protecting the rights of all persons within its territory-has ceded de facto administration of the camps to a liberation movement that is not formally accountable in the international system for its human rights practices.

However, despite this international obligation OHCHR (para. 39) notes that:

While the [Sahrawi] refugees are present in the territory of Algeria, the [Algerian] authorities reiterated during meetings with ... the [OHCHR] delegation that despite this presence, the responsibility for human rights and any other related matters lies with the Government of the SADR.

Indeed, while the Spanish courts attempted to summon Algerian national responsibility to secure Mimouna's release from the camps, Algeria repeatedly asserted SADR's authority as the 'Government' of the Sahrawi people, and refused to comply with the letter rogatory, inviting the Spanish Government to enter into direct diplomatic communication with the SADR Government (Europa Press 2009b). However, although Mimouna's father challenged the Spanish judge "to go to the camps and speak with my wife and children there" (Albert 2009), neither the Spanish judge nor the Spanish Embassy in Algiers have the authority to do so given the Algerian government's refusal to cooperate. Rather, as noted by the lawyer in charge of Mimouna's case, "there is a juridical limbo whereby Spain does not recognise the Sahrawi Arab Republic as a state", while Algeria "does not consider the case to be its own, since the Polisario Front has its own tribunal and is 
recognised by Algeria" (quoted in Radio Lucena 2009). Algeria's refusal to cooperate with the Spanish authorities in this case is also particularly notable given that Algeria had granted Mimouna a passport, but not Algerian citizenship, highlighting another anomaly in the Sahrawi context: refugees have access to various passports and travel documents to enhance their mobility for education, health and employment, without such passports embodying a legal tie with the granting state itself.

This case-study therefore demonstrates the extent to which state and non-state actors in a country such as Spain may use different means to 'reach' outside of its borders in order to 'protect' non-citizen women who were 'abducted' from its territory (and its families). While both Polisario and the Algerian government actively evaded the invocation of their responsibility to offer protection to Mimouna, it is notable that Spanish families, civil society and politico-legal actors alike should have so proactively developed a multifaceted strategy to secure Mimouna's 'release' from the camps, and her 'return home' to Spain. Such strategies included two failed 'liberation' attempts by members of Spanish civil society who intended to 'free' Mimouna from the camps (Caravaca 2009), and Mimouna's boyfriend's eventual 'success' in 'saving' her from her mother at the Algerian port of Oran in December 2009. In many ways, building upon the 'appropriation' of Sahrawi children fostered by Spanish families noted above, Spanish claims to protect Mimouna (and Aicha, Fatimetu and Huria before her) were founded upon an equation of Sahrawi girls and women with 'us' (where us=Spain), leading to the representation of a Spanish need to protect 'our' Sahrawi refugee women from 'their' Sahrawi culture and family. 
In many respects, representations and perceptions of Sahrawi refugee girls' and women's 'moral membership' ${ }^{5}$ of Spanish families and broader society can be traced to earlier colonial ties, and elements of 'colonial guilt' felt by Spanish civil society due to Spain's failure to appropriately decolonise the Western Sahara and its inhabitants; members of Spanish civil society regularly assert Spain's responsibility for the Sahrawis' protracted exile, a feeling of moral and political responsibility which underpins the solidarity movement which provides Polisario/SADR with essential humanitarian and political support (Fiddian-Qasmiyeh 2011).

More importantly, perhaps, these cases demonstrate the extent to which Spanish foster-families and Spanish civil society are perceived and widely represented in the Spanish media and politico-legal institutions as holding greater legitimacy than Sahrawi families over 'their' daughters. In these high-profile campaigns, the 'protection' of Sahrawi refugee women is invoked and pursued by Spanish non-state actors who declare their own moral and legal obligation to liberate 'our' oppressed girls and women from 'their' oppressive households and culture by demanding that the Spanish state, Polisario/SADR, and/or the Algerian state enact their politico-legal authority over these young female subjects.

\section{Conclusion}

By analysing the high-profile campaigns surrounding the 'abduction' of four Sahrawi refugee young women between 2002 and 2009, this article has examined the gendered protection narratives invoked by diverse state and non-state actors to secure Aicha's, Huria's, Fatimetu's and Maimouna's 'liberation' from their birth-families and birth- 
camps. While a number of boys and young men have also reportedly been 'returned' to the camps by their birth-families following short- and long-term fostering arrangements in Spain, the degree of public attention and anxiety expressed over the need to 'protect' these Sahrawi girls and women from their families is particularly notable, reflecting the extent to which gender, age and religion intersect in the identification of which migrant bodies warrant, and indeed deserve, state protection across different geopolitical contexts. In the cases briefly explored above, it can be argued that relations of intimacy, belonging and responsibility to protect have been realigned to favour Spanish families (Aicha, Huria and Fatimetu's foster-parents on the one hand, and Mimouna's Spanish fiancé on the other) to the detriment of Sahrawi families. The young women's physical, emotional and discursive separation from their biological families has been paralleled by the delegitimisation of the Sahrawi birth-families' ties to their daughters and sisters, and the public naturalisation of the Spanish families' concern for and public interventions to 'save' these young women from their 'ignorant' and 'egotistic' parents (op cit). In line with broader literatures which recognise that "the intimate is a coproduction with the public" (Oswin and Olund 2010,60), the intimate ties between the young women, their Spanish families, and Spanish society more broadly have been publically reinforced, solidified and legitimated through these campaigns, which have in turn demanded both Spanish and Sahrawi interventions in Sahrawi intimate relations and intimate spheres.

In the cases explored above, a wide network of families, members of Spanish civil society and NGO workers, alongside Spanish officials including lawyers, judges and ministers, have declared themselves responsible for the 'protection' of female Sahrawi refugee 'abductees' outside of Spanish national territory. However, Spain's determination 
and ability to 'rescue' these women from their families in the Sahrawi camps has been greatly complicated in these cases by virtue of long-standing struggles over political and discursive control over the Sahrawi camps and their inhabitants. Since Polisario explicitly claims to represent and act as a 'state' towards its 'refugee-citizens', whilst both Algeria (the host-state) and Polisario have denied legal responsibility over 'abductees' such as Aicha, Fatimetu, Huria and Mimouna, the question of 'sovereignty' and legal responsibility over the inhabitants of the Sahrawi refugee camps is actively accentuated by such cases. With both Polisario and the Algerian government refusing to address these 'abductions,' Spanish assumptions regarding the necessity and justifiability of 'outside intervention' to 'protect' oppressed women are reinforced. As such, the Sahrawi refugee camps are increasingly viewed by Spain as "spaces in which [they, i.e. the Spanish authorities] are entitled to exercise a form of sovereignty." ${ }^{6}$ Indeed, it could be argued that Spanish interventions to monitor and influence intimate family/household relations are an effective means of controlling camp spaces which lie beyond Spain's national jurisdiction. In this sense, the intimate aid system which underpins the camps' material and political survival is characterised not only by intimate ties of dependency between families, but provide the foundations for diverse forms of intimate governmentality of Sahrawi family life and private spheres by Sahrawi and Spanish authorities alike.

Ironically, while the Sahrawi refugee camps have systematically been heralded as the "best run refugee camps in the world" (op cit) and as models of self-sufficiency characterised by democracy and gender equality, such cases threaten to reinforce outsiders' sense of the necessity and justifiability of their involvement and exertion of their power over the camps and their inhabitants. Equally, they solidify the more specific 
preference held by donor states that refugee camps should be administered by donor experts (Harrell-Bond 1986), and broader assumptions held by the international community regarding the necessity of 'outside experts' intervening to resolve refugee crises and to 'protect' refugee women across the south and the north alike.

\section{Acknowledgements}

This article is based upon research funded by the Economic and Social Research Council. Thanks and acknowledgements are due to the anonymous reviewers of this piece in addition to the GPC Editorial Team and colleagues at the Refugee Studies Centre for their detailed comments on earlier versions of this paper; I am particularly grateful to Yousif M. Qasmiyeh for his support and sharing invaluable insights throughout my research. Any errors, of course, remain my own.

\section{Notes}

\footnotetext{
${ }^{1}$ All translations from Spanish are my own.

${ }^{2}$ The term 'tentacles' is used in the case of a British-Pakistani dual national facing forced marriage in Pakistan, in which Justice Hogg concludes that "in these dire and exceptional circumstances the tentacles of the court could stretch towards Pakistan to rescue a girl who was and always had been a British child and who was seeking British help" (RB v FB and MA [2008], 1624; emphasis added).

${ }^{3}$ See www.elparchedigital.com/pags/huria/Documento_acogimiento.doc (accessed: 10 December 2005) for a completed fostering agreement.
} 
4 "Broadly defined, a letter rogatory is a formal request from a court of one country to a court of another to perform some judicial act. The act requested may be service of summons, subpoena, or other legal notice, the taking of evidence, or the execution of a civil judgment" (see Gerber 1964, 1379).

${ }^{5}$ Gibney, personal communication, 7 July 2011.

${ }^{6}$ While applied here to Spain's relationship with the "spaces" of the Sahrawi refugee camps, in the original citation Verdirame is discussing the UNHCR's dominance and control over refugee camps elsewhere, noting the UNHCR's power to prevent external observers from entering "their" camps, despite permission having been granted by the host government $(1999,70)$.

\section{Notes on Contributor}

Elena Fiddian-Qasmiyeh is departmental lecturer in Forced Migration at the Refugee Studies Centre (University of Oxford) where she lectures on the MSc core course in 'Research Methods in Forced Migration' and convenes the MSc option in 'Gender, Generation and Forced Migration.' She has conducted research with Middle Eastern and North African refugees in Algeria, Cuba, Egypt, France, South Africa, Spain, Syria and the UK, and she focuses in particular on the intersections between gender, generation, religious identity, and asylum across these locations. Elena is the Director of the Refugee Studies Centre's International Summer School in Forced Migration, in addition to being book review editor for the Journal of Refugee Studies. She has previously worked as a legal advisor for refugees in Cairo (with AMERA-Egypt), and as a refugee case-worker with Amnesty International Australia's Refugee Team.

\section{References}


Abu-Lughod, L. 2002. Do Muslim Women Really Need Saving? Anthropological Reflections on Cultural Relativism and its Others. American Anthropologist 104: 783-90.

Albert, M. J. 2009. Detención ilegal o asuntos de familia: El padre de la chica saharaui de Lucena niega que la retenga en Argelia. El Pais, 16 February 2009, http://elpais.com/diario/2009/02/16/andalucia/1234740131_850215.html.

Ali, Ahmed. 2001. Al-Qur'an. A contemporary translation by Ahmed Ali. Translated by Ahmed Ali. New Jersey: Princeton University Press.

Alonso, L. M. 2003. Esperanza: Firmas. El parche digital, at http://www.elparchedigital.com/pags/firmas_lmalonso.htm

Akram, S. M. 2000. Orientalism Revised in Asylum and Refugee Claims. International Journal of Refugee Law 12 (1): 7-40.

Betteridge, A. H. 1985. Gift Exchange in Iran: The Locus of Self-identity in Social Interaction. Anthropological Quarterly 58: 190-202.

Bloch, A., T. Galvin, and B. Harrell-Bond. 2000. Refugee Women in Europe: Some Aspects of the Legal and Policy Dimensions. International Migration 38 (2): 169190.

Brazier, C. 1997. Special Edition: War and Peace in Western Sahara. The New Internationalist (297)

Castaño-Boullón, M. C. 2003. Sr. Director, at www.entendersahara.com/articulo.php?sec_documentos\&id_11 
Caravaca, T. 2009. Recogen firmas para liberar a una saharaui 'secuestrada' en Tinduf. El Mundo, 22 February 2009, http://www.elmundo.es/elmundo/2009/02/22/espana/1235326212.html.

Cazón, P. 2004. Lágrimas de arena: la historia de Aicha Embarek. Barcelona: El Aleph.

Chatty, D. 2010. Introduction. In Deterritorialised Afghan and Sahrawi Youth: Refugees from the Margins of the Middle East, ed. D. Chatty, 1-34. Oxford: Berghahn Books.

Chatty, D., Fiddian-Qasmiyeh and G. Crivello. 2010. Identity With/out Territory: Sahrawi Refugee Youth in Transnational Space. In Deterritorialised Afghan and Sahrawi Youth: Refugees from the Margins of the Middle East, ed. D. Chatty, 3784. Oxford: Berghahn Books.

Chopra, J., ed. 1999. Peace-maintenance: The Evolution of International Political Authority. London: Routledge.

Cohen, J., M. Nussbaum, and M. Howard, eds. 1999. Is Multiculturalism Bad for Women? Susan Moller Okin with Respondents. Princeton: Princeton University Press.

Crivello, G., E. Fiddian, and D. Chatty. 2005. Lessons Learned Report: the Transnationalisation of Care: Sahrawi Refugee Children in a Spanish Host Programme. Oxford: RSC.

Crivello, G., and E. Fiddian-Qasmiyeh. 2010. The Ties that Bind: Sahrawi Children and the Mediation of Aid in Exile. In Deterritorialized Youth: Sahrawi and Afghan Refugees at the Margins of the Middle East, ed. D. Chatty, 85-118. Oxford: Berghahn Books. 
Delegación Saharaui Castilla y León. 2002. Memorando. Valladolid, 2 May 2002. http://es.geocities.com/aichaembarek2/constitucion/carta_ayunta_2.JPG

Díaz, L. 2003. La Asociación Critica a la Familia Asturiana: Amigos del Sáhara rechaza la vuelta de Huria. La Voz de Asturias, 16 July 2003. http://archivo.lavozdeasturias.es/html/71799.html

Dustin, M. and A. Phillips. 2008. Whose agenda is it? Abuses of women and abuses of 'culture' in Britain. Ethnicities 8 (3): 405-424.

Embarek, A. N.D. Para las autoridades españolas. Accessed 1 January 2008).http://es.geocities.com/aichaembarek2/primeracarta/cartaautoridades

Europa Press. 2010. Garzón pide permiso a Argelia para interrogar a 13 víctimas del presunto genocidio de Marruecos en el Sáhara. Europa Press 5 January 2010.

Europa Press. 2009a. Argelia se inhibe en la comisión rogatoria sobre el caso de Mimouna. Europa Press, 24 May 2009.

Europa Press. 2009b. La Guardia Civil de Valencia detiene al hermano de una joven supuestamente retenida en Tindouf. Europa Press, 23 June 2009.

Farmer, A. 2006. Refugee responses, state-like behavior, and accountability for human rights violations: a case study of sexual violence in Guinea's refugee camps. Yale Human Rights and Development Law Journal 9 (44): 44-84.

Fernández, E. 2003. Movilización por la niña mariposa. El Mundo, 07 September 2003.

Fiddian, E. 2006. Education in Exile: Gendered Dilemmas. Gender Studies Centre, University of Cambridge, 09 February 2006.

Fiddian-Qasmiyeh, E. 2011a. Histories of Displacement: Intersections between ethnicity, gender and class. Journal of North African Studies 16 (1): 31-48. 
Fiddian-Qasmiyeh, E. 2011b. Protracted Sahrawi Displacement: Challenges and Opportunities Beyond Encampment. RSC Policy Briefing No. 7.

Fiddian-Qasmiyeh, E. 2010a. When the Self becomes Other: Representations of Gender, Islam and the Politics of Survival in the Sahrawi Refugee Camps. In Dispossession and Displacement: Forced Migration in the Middle East and North Africa, eds. D. Chatty and B. Findlay, 171-196. Oxford: Oxford University Press. Fiddian-Qasmiyeh, E. 2010b. 'Ideal' Refugee Women and Gender Equality Mainstreaming: ‘Good Practice' for Whom?' Refugee Survey Quarterly 29 (2): 64-84.

Fiddian-Qasmiyeh, E. 2009. Gender, Islam and the Sahrawi Politics of Survival. DPhil Thesis, University of Oxford.

Gerber, R. 1964. Revitalization of the International Judicial Assistance Procedures of the United States: Service of Documents and Taking of Testimony. Michigan Law Review 62 (8): 1375-1397.

González, J. 2003a. Denuncian la "retención" de una joven saharaui por su familia. La pareja con la que vivió una adolescente en Avilés reúne 12.000 firmas de apoyo. La Voz de Asturias, 13 July 2003.

González, J. 2003b. Servicios sociales no cree que la niña saharaui vuelva a Avilés. La Voz de Asturias, 05 August 2003.

Grupo de Amistad de la Comunidad Riojana. 2001. Estimado Sr. Ministro. http://es.geocities.com/aichaembarek2/otroscasos/Maribel_Carta1.gif Guijarro, F. 2003. La mujer saharaui sigue. http://www.entendersahara.com/articulo.php?sec_comentario\&id_23 
Hamoudi, H.(2003. Carta a la Reina de España.

http://www.elparchedigital.com/pags/huria/ruedadeprensa_20Dic2003.htm Harrell-Bond, B. E. 1986. Imposing Aid: Emergency Assistance to Refugees. Oxford: OUP.

Hossain, S. and S. Turner. 2001. Abduction for Forced Marriage - Rights and Remedies in Bangladesh and Pakistan. International Family Law 15-24.

Human Rights Watch. 2008. Human Rights in Western Sahara and in the Tindouf Refugee Camps: Morocco/Western Sahara/Algeria. New York: HRW.

Indra, D. 1989. Ethnic Human Rights and Feminist Theory: Gender Implications for Refugee Studies and Practice. Journal of Refugee Studies 2 (2): 221-242.

Indra, D. 1999. Not a 'Room of One's Own': Engendering Forced Migration and Practice. In Engendering forced migration: theory and practice, ed. D. M. Indra, 1-22. Oxford: Berghahn.

Kandiyoti, D. 2004. Political Fiction Meets Gender Myth: Post-conflict Reconstruction, 'Democratisation' and Women's Rights. IDS Bulletin 35 (4): 134.

Lynn-Price, D. 1981. The Western Sahara. London: Sage.

Matsuoka, A. and J. Sorensen. 1999. Eritrean Canadian Refugee Households as sites of gender renegotiation. In Engendering Forced Migration: Theory and Practice, ed. D. Indra, 218-241. New York: Berghahn Books.

Mercer, J. 1979. The Sahrawis of Western Sahara. London: Minority Rights Group. Mernissi, F. 2003. Beyond the Veil: Male-Female Dynamics in Modern Muslim Society. London: Saqi Books. 
Mohanty, C. T. 1988. Under Western Eyes: Feminist Scholarship and Colonial Discourses. Feminist Review 61-88.

M.P. 2008a. El juez investiga una denuncia de secuestro de una saharaui. El Pais, 20 August 2008.

M.P. 2008b. El padre de la supuestamente secuestrada dice que está a salvo en Tinduf. El País, 21 August 2008.

N.A. N.D. Introducción. Accessed: 01 November 2005. http://www.elparchedigital.com/pags/huria/CASO_INTRODUCCION.htm

Nader, L. 1989. Orientalism, Occidentalism and the Control of Women. Cultural dynamics 2 (3): 323-355.

OHCHR. 2006. Report of the OHCHR Mission to Western Sahara and the Refugee Camps in Tindouf - 15/23 May and 19 June 2006. Geneva: OHCHR.

Okin, S. M. 1998. Feminism and Multiculturalism: Some Tensions. Ethics 108: 661-84.

Peregil, F. 2002. El tormento de Aicha. El País, 26 May 2002. http://elpais.com/diario/2002/05/26/espana/1022364009_850215.html

Phillips, A. 2007. Multiculturalism Without Culture. Princeton: Princeton University Press.

Phillips, A. 2003. When Culture Means Gender: Issues of Cultural Defence in the English Courts. Modern Law Review 66 (4): 510-531.

Phillips, A. and M. Dustin. 2004. UK initiatives on forced marriage: regulation, dialogue and exit. Political Studies 52 (3): 531-551.

Planelles, M. 2009. Una juez culpa a una familia saharaui de raptar a su hija y llevarla a Argelia. El Pais, 13 December 2009. 
Radio Lucena. 2009. La familia del novio de Maimuna inicia una campaña de recogida de firmas. Radio Lucena, 25 June 2009. http://www.radiolucena.es/detalleNoticia.aspx?ID=1923

Roggeband, C. and M. Verloo. 2007. Dutch Women are Liberated, Migrant Women are a Problem: The Evolution of Policy Frames on Gender and Migration in the Netherlands, 1995-2005. Social Policy and Administration 41 (3): 271-288.

Spivak, G. C. 1993. "Can the subaltern speak?” In Colonial discourse and post-colonial theory, eds. P. Williams and L. Chrisman, 66-111. New York:Harvester Wheatsheaf.

Stabile, C. A. and D. Kumar. 2005. Unveiling Imperialism: Media, Gender and the War on Afghanistan. Media Culture Society 27: 765-82.

Suarez, I. 2003. Aicha Embarek, la Hurí de ojos negros y piel canela. El ParcheDigital. www.elparchedigital.com/pags.huria/ruedaprensa_20Dic2003.htm

Tapias, A. 2003. Querida familia acogedora. http:// www.entendersahara.com/articulo.php?sec_documentos\&id_11

UNHCR. 1995. Sexual Violence against Refugees: Guidelines on Prevention and Response. Geneva: UNHCR.

UNHCR. 2002. Guidelines on International Protection: Gender-Related Persecution within the Context of Article 1A(2) of the 1951 Convention and/or its 1967 Protocol relating to the Status of Refugees. Geneva: UNHCR.

UNHCR. 2009. Guidance Note on Refugee Claims relating to Female Genital Mutilation. Geneva: UNHCR 
Verdirame, G. 1999. Report: the rights of refugees in Kenya: a socio-legal study. http://www.forcedmigration.org.

Volpp, L. 2001. Feminism versus Multiculturalism' Columbia Law Review. 101 (5): $1181-1218$

Volpp, L. 1996. Talking 'Culture': Gender, Race, Nation and the Politics of Multiculturalism. Columbia Law Review 96 (6): 1573-1617.

Voutira, E. and B. E. Harrell-Bond. 2000. 'Successful' Refugee Settlement: Are Past Examples Relevant? In Risks and Reconstruction: Experiences of Resettlers and Refugees, eds. M. M. Cernea and C. McDowell, 56-76. Washington: World Bank.

Wilson, H. A. 1988. International Law and the Use of Force by National Liberation Movements. Oxford: OUP.

World Food Programme. 2008. Protracted Relief and Recovery Operation: Algeria 10172.2: Assistance to the Western Saharan Refugees.

Wurud. 2008. Wurud Sahra Blog. http://wurudsahrablogspotcom-wurud.blogspot.com 